\title{
Effect of Admixture on Physical and Mechanical Properties of Recycled Brick Aggregate Concrete
}

\author{
Md. Jahidul Islam ${ }^{1}$, Md. Shahjalal2 ${ }^{2}$ Md. Mehedi Hasan ${ }^{3}$, and Zarin Tasnim Chowdhury ${ }^{4}$ \\ Department of Civil Engineering, Military Institute of Science and Technology (MIST), Dhaka, Bangladesh \\ emails: ${ }^{*}{ }^{1}$ mjislam@ce.mist.ac.bd; ${ }^{2}$ shahjalal@ce.mist.ac.bd; ${ }^{3}$ mehediopu74@gmail.com; and ${ }^{4}$ zarintasnimch117@gmail.com
}

\section{ART I C L E I N F O \\ Article History: \\ Received: $18^{\text {th }}$ January 2021 \\ Revised: 25 ${ }^{\text {th }}$ March 2021 \\ Accepted: $31^{\text {th }}$ March 2021 \\ Published: 27th June 2021}

\section{Keywords:}

Recycled Brick Aggregate

Chemical Admixture

Compressive Strength

Tensile Strength

High-Temperature Exposure

\begin{abstract}
A B S T RAC T
With the increasing population of the world, the rate of development of infrastructure is increasing day by day; which has placed a massive demand for natural aggregates. Besides, huge amount of demolished construction wastes are generated all over the world which creates pressure on the environment as well as landfills. Therefore, it is necessary to find a sustainable solution to adopt these C\&D wastes as an alternative to natural aggregates for construction purposes. Therefore, the objective of the present study is to explore the influence of superplasticizers while adopting recycled brick aggregate (RBA) in the sustainable concrete application as a coarse aggregate. Six different mixes are considered with $100 \%$ replacement of recycled brick aggregate and three diverse water-cement $(\mathrm{w} / \mathrm{c})$ ratios, such as $0.40,0.45$, and 0.50 . To improve the workability and mechanical characteristics of concrete a superplasticizer is used as an admixture. Fresh properties of concrete, compressive strength at normal and high temperatures, flexural strength and splitting tensile strength are presented. The results indicate that addion of superplasticizer improves slump values and reduces air voids of concrete. Although strengths of RBA concrete are lesser than the virgin brick aggregate concrete, they are still satisfactory in the application for structural concrete and can be also significantly improved by incorporating admixture. Finally, this research will help to recycle the brick aggregate instead of dumping it as waste in a landfill.
\end{abstract}

\section{INTRODUCTION}

The concrete industry is facing towering challenges to meet up the consumption of natural resources such as natural stone and sand because of the growing demand for production and utilization of concrete all over the world. Every year almost 17.5 billion tons of concrete are produced worldwide which equals 2.5 tons of concrete per person per year (Barcelo, 2013; Mehta, 2009). To meet this demand almost 10 to 12 billion tons of aggregates are used all over the world per year (Smith, 2010). Aggregates are generally collected by mining stone quarries and staving river gravels. In near future, stone quaries will dry up and sources for natural aggregate will be exhausted.

A large amount of demolished construction waste is generated from the repair work of old infrastructures. Almost 2-3 billion tons of demolished concrete is estimated globally which is $30 \%$ to $40 \%$ of total solid wastes (C\&D Waste Management Guide, 2016; Rodríguez-Robles et al., 2015). In many parts of the world, these wastes are dump into landfills. Therefore, it is necessary to release this pressure on land sites as well as to find the alternative of natural aggregates for construction purposes. One of the possible solutions is to reuse them in such a way where these $C \& D$ wastes cannot affect the environment. Various research has been conducted to reuse the alternative materials like recycled stones and crumb rubber (Hossain et al., 2019; Shahjalal et al., 2019; Shahjalal et al., 2021), FRP scrap aggregate (Alam et al., 2013), Poly-Ethylene Terephthalate (PET) (Islam et al., 2018; Islam et al., 2016), brick (Islam et al., 2020) recycled brick (Mohammed et al., 2015), etc.

Many of the old structures in Bangladesh are constructed with bricks that are now out of their service and the brick aggregates obtained from these demolished structures can be used in new structures as coarse aggregate. Sustainable construction has gotten much attention among researchers to design and construct sustainable, resilient, and environmentally friendly structures. Therefore, it is 
essential to identify the properties of these recycle waste materials before using them in structural concrete.

Mohammed et al. (2015) collected recycled brick aggregate from various building sites of different ages. From their study they found that up to $50 \%$ replacement of virgin first-class brick aggregates (FBA) by recycled brick aggregates (RBA), there is very little change in compressive strength of concrete. It was also found that about $20.7 \mathrm{MPa}$ to $31 \mathrm{MPa}$ concrete can be made easily with RBA and the workability of concrete made with RBA is lower than the concrete prepared with FBA. Another study found that for the w/c ratio of 0.45 and 0.55 , the average strength of RBA concrete was $24.7 \mathrm{MPa}$ and 20.4 $\mathrm{MPa}$, respectively which is very close to the available design strength of concrete used in Bangladesh for various structures (Mohammed et al., 2013b). Mohammed and Hasnat (2014) found no significant difference in modulus of rapture and splitting tensile strength of RBA concrete compared with virgin FBA concrete.

Mohammed et al. (2013a) tried to improve the workability of recycled aggregate concrete (RAC) where aggregates were coated with cement paste; and found that the application of coating over the RCA can improve the workability of concrete and reduce the absorption capacity of aggregate. In the case of mechanical properties, like compressive and splitting tensile strengths, and Young's Modulus of concrete, a benefit of the coating was found for w/c of 0.55 ; but not found any significant improvement for w/c ratio of 0.45 .

The durability properties of RAC can be strongly influenced by the higher water absorption capacity and porosity of RCA. Kou et al. (2011) studied the pore size distribution and long-term mechanical properties of recycled aggregate concrete (RAC). It was observed that the porosity of RBA had a higher value compared to the crushed new brick aggregates and had a higher water requirement when used as aggregate in concrete. It was also found that the porosity and compressive strength had an inverse relationship for RBA concrete.

It is conceivable to obtain comparatively higher compressive strength from RAC than natural aggregate concrete (NAC); and the properties of RAC can be significantly improved by using superplasticizers admixture and silica fume (Ajdukiewicz \& Kliszczewicz, 2002). Ajdukiewicz and Kliszczewicz (2002) found that with an application of admixtures RAC of $80 \mathrm{MPa}$ was achievable from NAC of $60 \mathrm{MPa}$.

Kou et al. (2014) worked with the effects of high temperature $\left(300^{\circ} \mathrm{C}, 500^{\circ} \mathrm{C}\right.$, and $\left.800^{\circ} \mathrm{C}\right)$ exposure of RBA concrete. Before exposure the concrete to high temperature, the NAC showed lower capillary absorption capacity and higher compressive strength than that of RBA concrete. After exposure to $300^{\circ} \mathrm{C}$, though the mechanical properties of all concrete (NAC and RBA concrete) improved, the capillary absorption capacity increased. On the other hand, it was seen that after exposure to $500^{\circ} \mathrm{C}$ and $800^{\circ} \mathrm{C}$ the NAC suffered higher deteriorations than RAC for all the tested properties especially the splitting tensile strength as well as the capillary absorption capacity. The authors concluded that the RCA suffered fewer degradations in mechanical and durability properties than that of NCA at high temperatures.

In Bangladesh, many of the old infrastructures are constructed with brick aggregate which is now out of their services. A large amount of recycled brick aggregate will be generated in the future. So, it will be a great challenge to manage these huge demolished recycled brick concrete. From the literature, it is seen that using recycled aggregate can reduce the strength of concrete.Thus using admixture can play a significant role to improve this strength. One of the prime objectives of this study is to improve recycled aggregate concrete strength without increasing the cement content through addition of admixture. Besides, the mechanical behavior of recycled brick aggregate at high temperatures should also be investigated. Though the effect of admixtures, such as superplasticizers and hightemperature exposure on the physical and mechanical properties of concrete with recycled stone aggregate has been studied extensively, there are very limited studies yet to be reported on the physical and mechanical properties of concrete with recycled brick aggregate and superplasticizers subjected to elevated temperature exposure. Therefore, in the present study physical and mechanical behavior of RBA is studied while incorporating admixture and compare them with FBA as well as RBA concrete without admixture.

\section{EXPERIMENTAL INVESTIGATION}

\section{A. Materials}

The materials used for concrete mixtures include virgin first-class brick aggregate (FBA), recycled brick aggregate (RBA), natural fine aggregate (NFA), Portland composite cement (PCC), and admixture. The RBA was collected from the demolished brick concrete blocks of a 30 years old residential building shown in Figure 1. Then the collected blocks were broken manually into three particular sizes such as $25 \mathrm{~mm}$ to $19.5 \mathrm{~mm}, 19.5 \mathrm{~mm}$ to $9.5 \mathrm{~mm}$, and $9.5 \mathrm{~mm}$ to $4.75 \mathrm{~mm}$ which was ensured by sieving them with a sieve shaker. After crushing into pieces, the aggregates were mixed as $5 \%$ retained on $19.5 \mathrm{~mm}, 60 \%$ retained on $9.5 \mathrm{~mm}$, and $35 \%$ retained on $4.75 \mathrm{~mm}$ seive as per ASTM (ASTM C33/C31M, 2018). The gradation of brick chips and NFA were selected in such a manner that they fall within the ASTM lower and upper limits (ASTM C33/C31M, 2018). The particle distribution plot of brick chips and NFA is presented in Figure 2. All the physical and mechanical properties of aggregates are summarized in Table 1. As shown in the table, the absorption capacity of RBA is higher than the FBA. Furthermore, mechanical properties, such as Los Angeles abrasion (LAA) value, aggregate crushing value (ACV), and aggregate impact value (AIV), for RBA is lower than the FBA indicating inferior aggregate quality.

Portland Composite Cement (PCC), specified as BDS EN 197-1:2010, CEM II/B-M (S-V-L) $42.5 \mathrm{~N}$, is the most common type of cement used in Bangladesh. It is relatively cheaper than Ordinary Portland Cement (OPC) and easily available in local market. Therefore, in the present study PCC is adopted as the binding material for concrete. The 
physical and chemical and physical properties of PCC were determined. The major chemical compounds of PCC are $\mathrm{CaO}-64.82 \%, \mathrm{Al}_{2} \mathrm{O}_{3}-4.74 \%, \mathrm{SiO}_{2}-20.60 \%, \mathrm{Fe}_{2} \mathrm{O}_{3}$ $-3.28 \%$, and LOI $-1.73 \%$. Specific gravity and normal consistency of PCC are 2.95 and $26.7 \%$, respectively. The admixture used in this study is a synthetic polymer-based high range water reducing superplasticizer following ASTM C494 (2019). This admixture is used to reduce the amount of mixing water while maintaining control on the extend of set retardation.

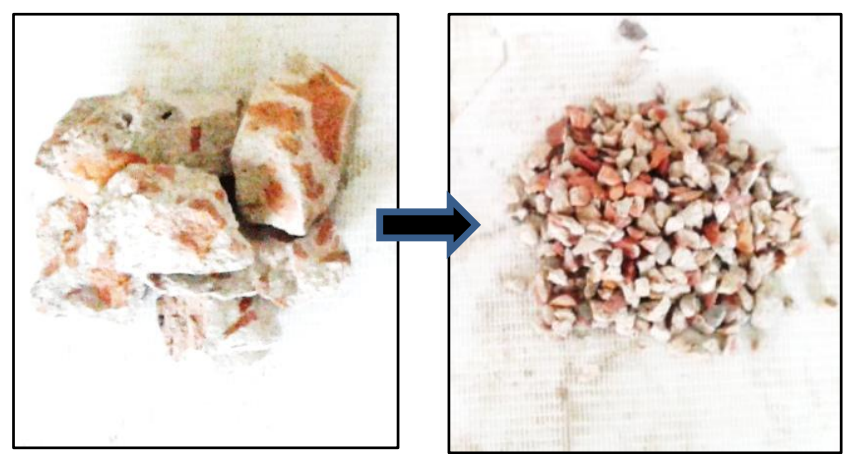

Figure 1: Demolished brick concrete block and recycled brick aggregates
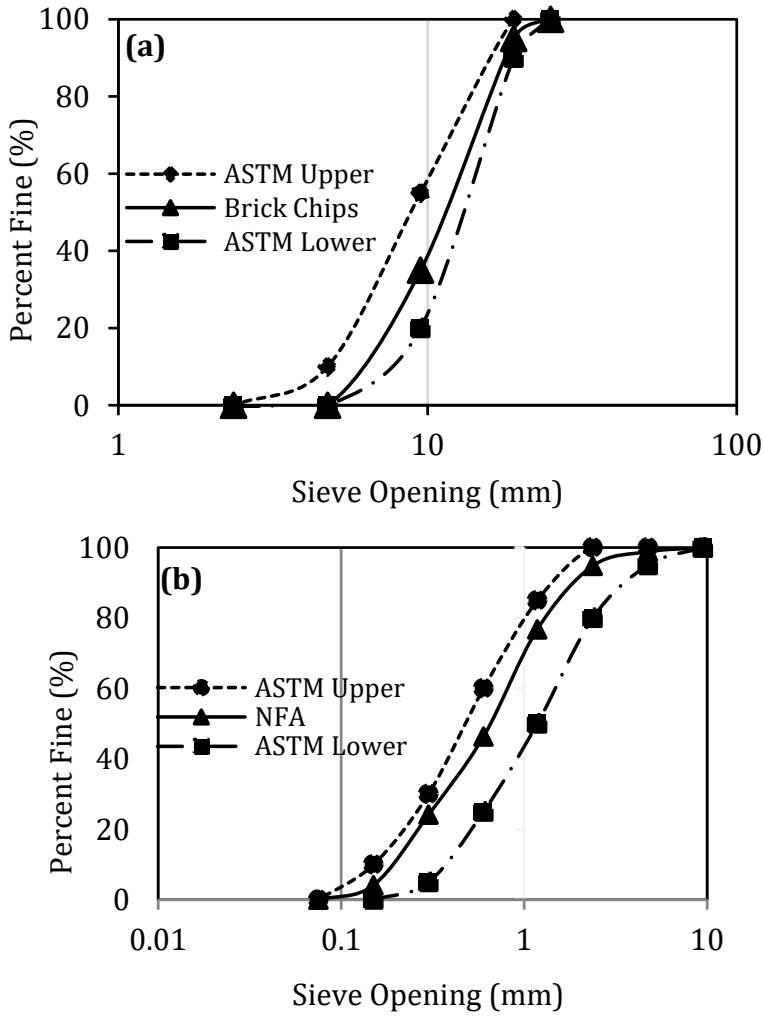

Figure 2: The gradation curve of (a) brick aggregate and (b) NFA

\section{B. Mixture Proportions}

Seven variant concrete mixtures were produced for this study. Among them, six of the mixtures were prepared with recycled brick aggregate (RBA) and the rest was made with virgin first-class brick aggregate (FBA). Watercement $(\mathrm{w} / \mathrm{c})$ ratios of $0.40,0.45$, and 0.50 were considered for RBA, and w/c ration of 0.50 is considered for virgin FBA, as a control mix, to compare the results. Among the six mixtures of RBAs, three of them were with admixture and the other three were without admixture. The mix proportions of the seven different mixes are summarized in Table 2. Each mix design is designated with a unique name for ease in referencing within the text. For example, Batch name $\mathrm{RB}_{40} \mathrm{~A}$ indicates that the coarse aggregate used in this mixture is RBA, 40 means the w/c ratio is 0.40 and ' $A$ ' is designated for admixture. The other batches are named in the same manner. On the other hand, $\mathrm{FB}_{50}$ means that the coarse aggregates used in this mixture are FBA, and 50 means the w/c ratio is 0.50 .

Table 1

Properties of FBA, RBA and NFA

\begin{tabular}{lccc}
\hline \hline Variables & FBA & RBA & NFA \\
\hline SSD Specific Gravity & 2.08 & 1.98 & 2.37 \\
OD Specific Gravity & 1.96 & 1.82 & 2.32 \\
Absorption Capacity (\%) & 14.55 & 18.74 & 1.87 \\
Fineness Modulus & 7.05 & 7.05 & 2.55 \\
\hline Unit Weight-Loose $\left(\mathrm{kg} / \mathrm{m}^{3}\right)$ & 958 & 999 & 1476 \\
Unit Weight-Compact $\left(\mathrm{kg} / \mathrm{m}^{3}\right)$ & 1022 & 1055 & 1557 \\
Void \% (Loose) & 45.9 & 38.7 & 40.1 \\
Void \% (Compact) & 43.2 & 37.2 & 35.7 \\
\hline LAA value (\%) & 37 & 43.5 & - \\
ACV (\%) & 30 & 40 & - \\
AIV (\%) & 36 & 44 & - \\
\hline \hline
\end{tabular}

\section{Specimens}

A total of 126 cylinders $(200 \mathrm{~mm}$ height $\times 100 \mathrm{~mm}$ diameter) were prepared to determine different properties of concrete. The compressive strength was determined after 7 days, 28 days, and 56 days at normal temperature and to determine the change of compressive strength in high temperature two different temperatures are used $\left(400^{\circ} \mathrm{C}\right.$ and $\left.600^{\circ} \mathrm{C}\right)$. After 28 days the concrete cylinder samples were exposed to higher temperatures of $400^{\circ} \mathrm{C}$ and $600^{\circ} \mathrm{C}$ with the help of an electric oven. It took the oven about 10 minutes to reach the peak temperatures and then the samples were kept at a constant temperature for an hour. After an hour the oven was turned off and samples were then cooled down. Once the sample was cool down to room temperature the compressive strength test was done. The splitting tensile strength of concrete was determined at 28 days.

To determine the flexural strength of concrete, a total of 21 beams with a sample size of $100 \mathrm{~mm} \times 100 \mathrm{~mm} \times 500 \mathrm{~mm}$ were prepared. The test was done at 28 days. A vibrator was used to compact the fresh concrete in molds. After casting, the specimens were kept in a controlled room for 24 hours, and then demolded. After demolding, the specimens were cured in a water curing tank at a constant temperature $\left(23 \pm 1^{\circ} \mathrm{C}\right)$ for 28 days except for samples that were tested at 7 days. 
Table 2

The proportion of water, cement, aggregates, and admixture for a cubic meter of concrete

\begin{tabular}{ccccccc}
\hline \hline $\begin{array}{c}\text { Batch } \\
\text { Code }\end{array}$ & $\begin{array}{c}\text { W/C } \\
\text { Ratio }\end{array}$ & $\begin{array}{c}\text { Water } \\
\text { (kg) }\end{array}$ & $\begin{array}{c}\text { Cement } \\
\text { (kg) }\end{array}$ & $\begin{array}{c}\text { FBA/ } \\
\text { RBA } \\
\text { (kg) }\end{array}$ & $\begin{array}{c}\text { NFA } \\
\text { (kg) }\end{array}$ & $\begin{array}{c}\text { Admixture } \\
\text { (l) }\end{array}$ \\
\hline $\mathrm{FB}_{50}$ & 0.50 & 205 & 410 & $675 \dagger$ & 720 & - \\
$\mathrm{RB}_{40}$ & 0.40 & 205 & 513 & 675 & 643 & - \\
$\mathrm{RB}_{45}$ & 0.45 & 205 & 456 & 675 & 686 & - \\
$\mathrm{RB}_{50}$ & 0.50 & 205 & 410 & 675 & 720 & - \\
\hline $\mathrm{RB}_{40} \mathrm{~A}$ & 0.40 & 185 & 513 & 675 & 685 & 1.29 \\
$\mathrm{RB}_{45} \mathrm{~A}$ & 0.45 & 185 & 456 & 675 & 729 & 1.11 \\
\hline $\mathrm{RB} 50 \mathrm{~A}$ & 0.50 & 185 & 410 & 675 & 765 & 0.92 \\
\hline \hline
\end{tabular}

Note: †FBA

\section{Testing Procedure}

Slump value test and air content test of fresh concrete samples were determined according to ASTM C143 (2015) and ASTM C231 (2017), respectively. The compressive strength test, as shown in Figure 3(a), was performed according to ASTM C39 (2018) and the loading rate was kept at $0.25 \pm 0.05 \mathrm{MPa} / \mathrm{s}$. The splitting tensile strength test was conducted following ASTM C496 (2014) and the flexural strength of the concrete prisms was perfomred following ASTM C78 (2016). The flexural strength test was performed at the one third point with a displacement rate of $0.15 \mathrm{~mm} / \mathrm{min}$. The tests set up for different tests are shown in Figure 3.
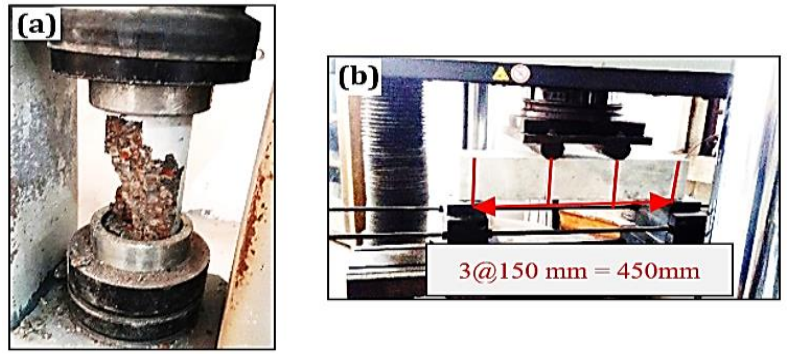

Figure 3: Test setup for (a) compression test (b) flexural test

\section{RESULTS AND DISCUSSIONS}

The effects of using RBA, on fresh and mechanical properties of concrete, such as workability, air content, compressive strength at room temperature and high temperature, splitting tensile and flexural strengths are presented in this section.

\section{A. Fresh Concrete Properties}

The slump values and air content of vaious combinations of concrete mixes are shown in Figure 4. Comparing between $\mathrm{FB}_{50}$ and $\mathrm{RB}_{50}$ it is observed that RBA concrete showed a slightly lower slump value $(112 \mathrm{~mm})$ than that of virgin FBA concrete $(115 \mathrm{~mm})$ due of its higher surface roughness and absorption capacity. Furthermore, slump values were increased with the increase in w/c ratio and with the incorporation of admixture into the concrete mix. On the other hand, the fresh air content value had an inverse relation with the w/c ratio. The lower $\mathrm{w} / \mathrm{c}$ ratio concrete showed the higher air content and it decreased when the admixture was added into the concrete by improving the flowablity of concrete. $\mathrm{RB}_{50} \mathrm{~A}$ showed the highest slump value $(124 \mathrm{~mm})$ and lowest air content value (1.97\%).

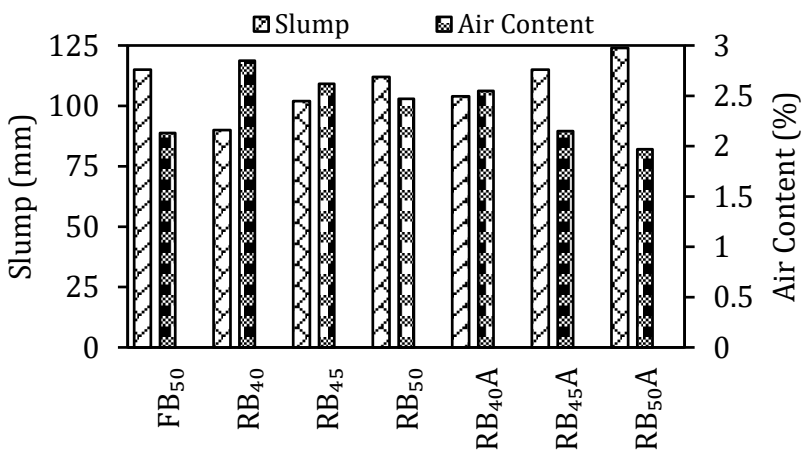

Figure 4: Sump value and air content of different concrete mixtures

\section{B. Compressive Strength}

The compressive strength of hardened concrete at 7, 28, and 56 days is presented in Figure 5. Overall, it is seen that the compressive strengths were increased by almost $36 \%$ and $46 \%$ at 28 days and 56 days compared to 7 days. For the w/c ratio of 0.5 , it is observed that the compressive strength of RBA concrete $\left(\mathrm{RB}_{50}\right)$ was decreased by $8.8 \%$ compared to virgin FBA concrete $\left(\mathrm{FB}_{50}\right)$ at 28 days. This may happen because of the mortar attached on the surface of the aggregate which may weaken the interfacial transition zone (ITZ) and have a weaker bond between the virgin cement mortar matrix and existing mortar on the aggregate surface. This behavior is consistent with the previous studies (Arabiyat et al., 2021; Hossain et al., 2019; Mohammed et al., 2015). After adding admixture with this RBA concrete of the same w/c ratio $\left(\mathrm{RB}_{50} \mathrm{~A}\right)$, the compressive strength was increased by $5.2 \%$ compared to the control mix $\left(\mathrm{FB}_{50}\right)$. When there was no admixture in RBA concrete, the compressive strength was decreased with the increasing w/c ratios. For the three different w/c ratios $(0.40,0.45$, and 0.50$)$, the compressive strengths varied from $41.40 \mathrm{MPa}$ to $47.55 \mathrm{MPa}$. After adding admixture this range varied from $47.72 \mathrm{MPa}$ to 52.94 $\mathrm{MPa}$. This incremental trend is also observed for compressive strengths at 7 days and 56 days. All the compressive strengths of RBA concrete were more than 40 $\mathrm{MPa}$ which is enough for structural concrete. The failure pattern of concrete cylinders subjected to compressive load is presented in Figure $6(\mathrm{a} \& \mathrm{~b})$. Most of the concrete cylinders showed cone and shear failure.

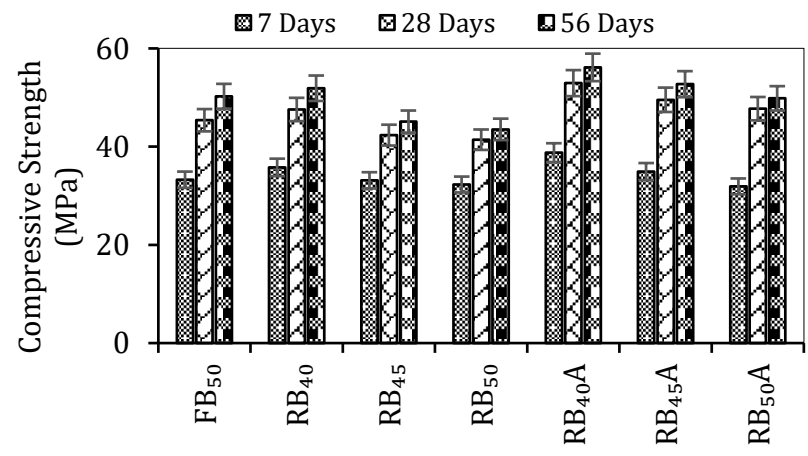

Figure 5: Variation in compressive strength of various combinations of concrete at different ages 

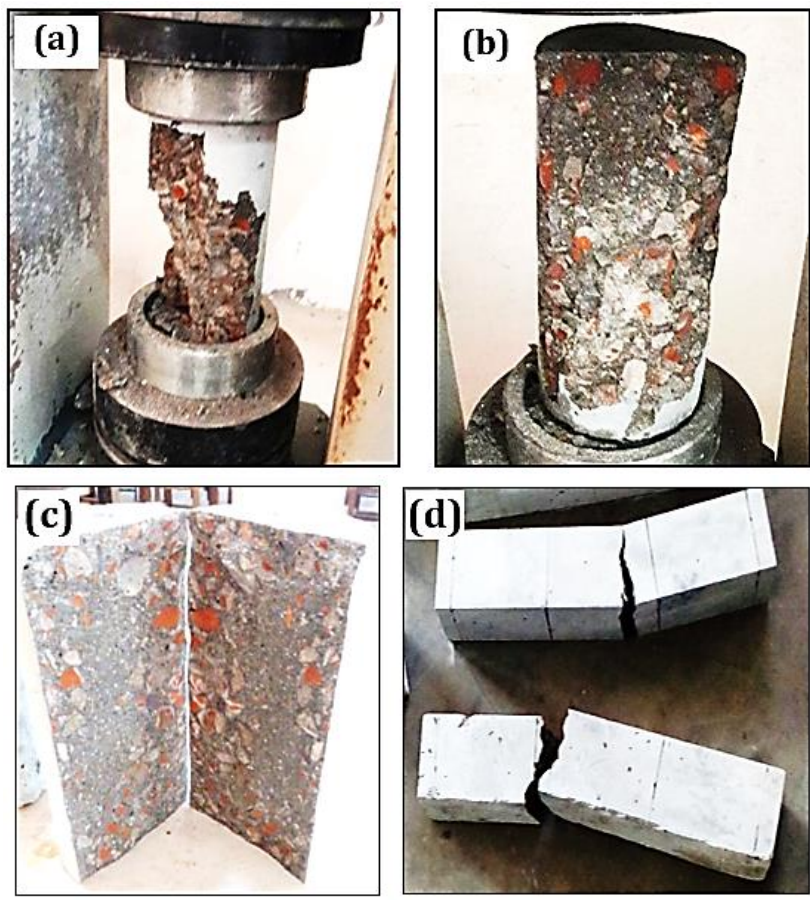

Figure 6: Failure pattern of the concrete cylinder under (a \& b) compressive strength test (c) splitting tensile strength test (d) beam flexural strength test

\section{Effect of Temperature on Compressive Strength}

Effect of high temperature on compressive strength of concete was studied. Concrete goes through mineralogical changes when subjected to heat. Around $250^{\circ} \mathrm{C}$ to $350^{\circ} \mathrm{C}$ temperature suffered damage because of the pore water pressure development. Furtheremore, at about $600^{\circ} \mathrm{C}$ reinforcements in reinforced concrete become half of its room temperature strength. Therefore, in the present study two tempartures were selected for high temperature study, that is $400^{\circ} \mathrm{C}$ and $600^{\circ} \mathrm{C}$.

The compressive strengths of concrete at 28 days after subjected to $0^{\circ} \mathrm{C}, 400^{\circ} \mathrm{C}$ and $600^{\circ} \mathrm{C}$ temperature is presented in Figure 7. After exposed to $400^{\circ} \mathrm{C}$, the compressive strengths of RBA concrete without admixture were decreased by $10.1 \%, 12.8 \%$, and $14.4 \%$ for the w/c ratio of $0.40,0.45$, and 0.50 , respectively compared to concrete compressive strength at room temperature; whereas, for $600^{\circ} \mathrm{C}$ exposure compressive strength were reduced by $26.3 \%, 24.7 \%$, and $32.2 \%$, respectively. On the other hand, for RBA concrete with admixture after exposed to $400^{\circ} \mathrm{C}$, the compressive strengths were decreased by $17.1 \%, 18.2 \%$, and $21.4 \%$ for the w/c ratio of $0.40,0.45$, and 0.50 , respectively; whereas, for $600^{\circ} \mathrm{C}$ exposure compressive strengths were reduced by $27.2 \%, 32.3 \%$, and $29.8 \%$, respectively. Reduction of compressive strength at $400^{\circ} \mathrm{C}$ temperature was higher for RBA with admixtures. However, at $600^{\circ} \mathrm{C}$ temperature, it became consistent with RBA without admixture.

\section{Splitting Tensile Strength}

The splitting tensile strengths of different concrete mixes are shown in Figure 8. The tensile strengths were decreased with increasing w/c ratio. For the w/c of 0.5 , the tensile strength of RBA concrete was decreased by $7.8 \%$ compared to virgin FBA concrete but it was increased by
$15.3 \%$ after adding admixture with it. For the w/c ratio of 0.40 , the tensile strength was $2.77 \mathrm{MPa}$ which was increased to $3.42 \mathrm{MPa}$ after adding admixture into it; and for the $0.45 \mathrm{w} / \mathrm{c}$ ratio this strength was $2.61 \mathrm{MPa}$ and 3.31 MPa without admixture and with admixture, respectively. For all cases of RBA concrete without admixture, the tensile strength was more than $2.45 \mathrm{MPa}$. It can be concluded that the tensile strengths are slightly decreased for RBA concrete and it can be easily compensated by adding admixture.

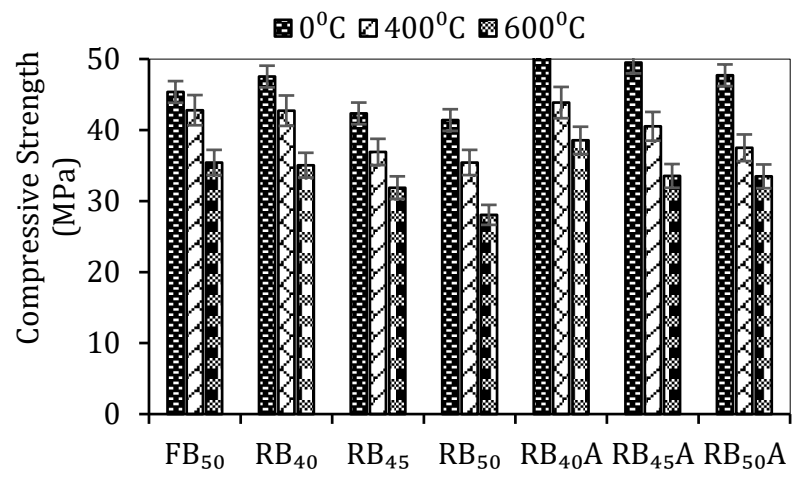

Figure 7: Compressive strengths at high temperature

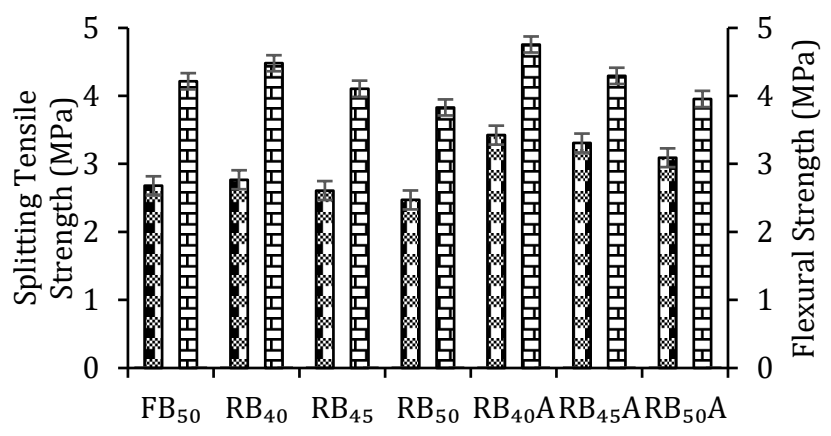

Figure 8: Variation in splitting tensile strength and flexural strength of different concrete mixtures at 28 days

\section{E. Flexural Strength}

The flexural strength of concrete of different batches is presented in Figure 8. The flexural strength shows a similar pattern to splitting tensile strength. Comparing between the same w/c ratio $(0.50)$ concrete composed with virgin brick aggregate $\left(\mathrm{FB}_{50}\right)$ and recycled brick aggregate $\left(\mathrm{RB}_{50}\right)$ it is seen that the flexural strength was decreased almost $9.1 \%$ for RBA. The recycled brick aggregate had a low water absorption capacity compare to the FBA which results in a higher free water in the concrete mixture which weakens the ITZ. The same pattern was also observed in previous studies (Hossain et al., 2019). However, Mohammed and Hasnat (2014) found almost no decernable changes in flexural strength of the recycled brick aggregate and first-class brick aggregate concrete. Reducing the w/c increases the flexural strength as observed from the test results. For the w/c ratio of 0.40 and 0.45 , these strengths were $4.48 \mathrm{MPa}$ and 4.11 MPa which were more than the w/c ratio of $0.5(3.83 \mathrm{MPa})$ for recycled brick. The addition of the admixture also increased the flexural strength of concrete. After adding admixture, the strengths were $4.76 \mathrm{MPa}, 4.30 \mathrm{MPa}$, and 3.96 MPa which were $6.1 \%, 4.6 \%$, and $3.3 \%$ more compared to the combinations without admixture. 


\section{F. Comparison of Strength Properties with the Standard Codes}

Studies show that there is a strong correlation between compressive strength and splitting tensile strength or flexural strength of concrete. To predict these strengths there exist various guidelines and equations. In this section, design recommendations from the ACI, CSA, Euro-code (EC2), fib, and available equations given by various researchers are used to predict the splitting tensile and flexural strengths of the concrete specimens which is illustrated in Table 3 and Figure 9. Then these predicted values are paralleled with the experimental results shown in Figure 10. From the ratio between theoretical and experimental values, it can be predicted whether the existing guidelines over-estimate or under-estimate the experimental results of recycled bricks. The ratio between theoretical and experimental values is greater than 1 means over-estimate while less than 1 means under-estimate the experimental result. It can be seen that all the equations show an over-prediction.

Table 3

Splitting tensile strength and module of rupture

\begin{tabular}{|c|c|c|}
\hline \multirow{4}{*}{$\begin{array}{l}\text { Splitting } \\
\text { tensile } \\
\text { strength }\end{array}$} & $\begin{array}{l}\text { ACI } 318 \\
(2014)\end{array}$ & $\begin{array}{l}t, s p=0.556 \sqrt{ } f_{C}^{\prime} \text {; where } f_{t, s p} \text { is } \\
\text { splitting tensile strength (MPa) } \\
\text { and } f_{C}^{\prime} \text { is the compressive strength } \\
\text { of concrete }(\mathrm{MPa}) \text {. }\end{array}$ \\
\hline & $\begin{array}{l}\text { fib2010 (fib, } \\
\text { 2010) }\end{array}$ & $\begin{array}{l}f_{t}=0.3\left(f_{C}^{\prime}\right)^{\frac{2}{3}} ; \text { where } f_{t} \text { is tensile } \\
\text { strength }(\mathrm{MPa}) \text { and } f_{C}^{\prime} \text { is } \\
\text { compressive strength }(\mathrm{MPa}) .\end{array}$ \\
\hline & $\begin{array}{l}\text { EC2 (EN 1992- } \\
1-1,2005)\end{array}$ & $\begin{array}{l}f_{t}=\alpha_{s p} f_{t, s p} \quad ; \quad \text { where EC2 } \\
\text { recommends the value of } \alpha_{s p} \text { as } 0.9\end{array}$ \\
\hline & $\begin{array}{l}\text { Mohammed et } \\
\text { al. (2015) }\end{array}$ & $\begin{array}{l}f_{t}=0.50 \sqrt{ } f_{C}^{\prime} ; \text { where } f_{t} \text { is tensile } \\
\text { strength }(\mathrm{MPa}) .\end{array}$ \\
\hline \multirow{6}{*}{$\begin{array}{l}\text { Modulus } \\
\text { of } \\
\text { rupture }\end{array}$} & $\begin{array}{l}\text { ACI } 318 \\
(2014)\end{array}$ & $\begin{array}{l}f_{r}^{\prime}=0.62 \sqrt{f_{c}^{\prime}} \text {; where } f_{r} \text { is the } \\
\text { modulus of rupture (MPa) and } f_{C}^{\prime} \\
\text { is in MPa. }\end{array}$ \\
\hline & $\begin{array}{l}\text { fib2010 (fib, } \\
2010)\end{array}$ & $\begin{array}{l}f_{r}^{\prime}=\frac{0.3\left(\left(f_{C}^{\prime}\right)^{\frac{2}{3}}\right)}{\alpha_{f l}} ; \text { where, } \alpha_{f l}= \\
\frac{0.06 h_{b}^{0.7}}{1+0.06 h_{b}^{0.7}} \text { and } h_{b}=\text { depth of beam } \\
(\mathrm{mm}) ; f_{C}^{\prime} \text { is in } \mathrm{MPa}\end{array}$ \\
\hline & $\begin{array}{l}\text { CSA A23.3-14 } \\
(2014)\end{array}$ & $\begin{array}{l}f_{r}^{\prime}=0.6 \lambda \sqrt{f_{c}^{\prime}} \text {; where } \lambda=1.0 \text { for } \\
\text { normal density concrete and } f_{C}^{\prime} \text { is } \\
\text { in MPa. }\end{array}$ \\
\hline & $\begin{array}{l}\text { Akhtaruzzaman } \\
\text { and Hasnat } \\
(1983)\end{array}$ & $\begin{array}{l}f_{r}=0.69 \sqrt{ } f_{C}^{\prime} ; \text { where } f_{r} \text { and } f_{C}^{\prime} \text { is in } \\
\text { MPa. }\end{array}$ \\
\hline & $\begin{array}{l}\text { Carasquillo et } \\
\text { al. (1981) }\end{array}$ & $\begin{array}{l}f_{r}=0.97 \sqrt{ } f_{C}^{\prime} ; \text { where where } f_{r} \text { and } \\
f_{C}^{\prime} \text { is in MPa. }\end{array}$ \\
\hline & $\begin{array}{l}\text { Mohammed } \\
\text { and Hasnat } \\
(2014)\end{array}$ & $\begin{array}{l}f_{r}=0.95 \sqrt{ } f_{C}^{\prime} ; \text { where where } f_{r} \text { and } \\
f_{C}^{\prime} \text { is in MPa. }\end{array}$ \\
\hline
\end{tabular}
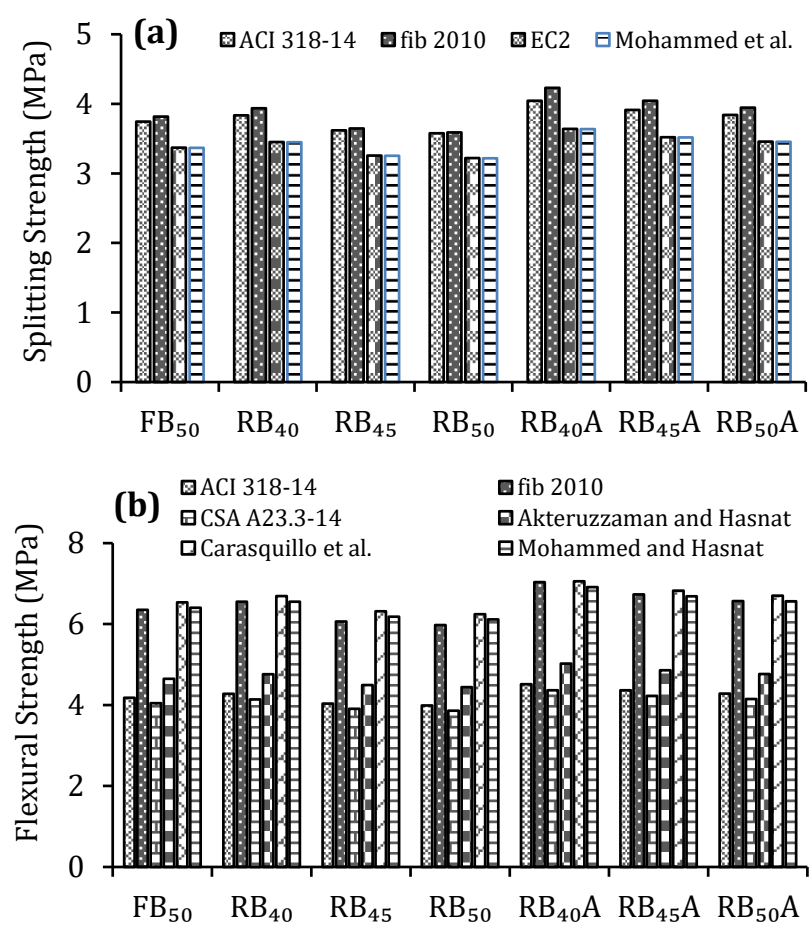

Figure 9: Comparison of (a) splitting tensile strength, and (b) flexural strength of concrete with different equations
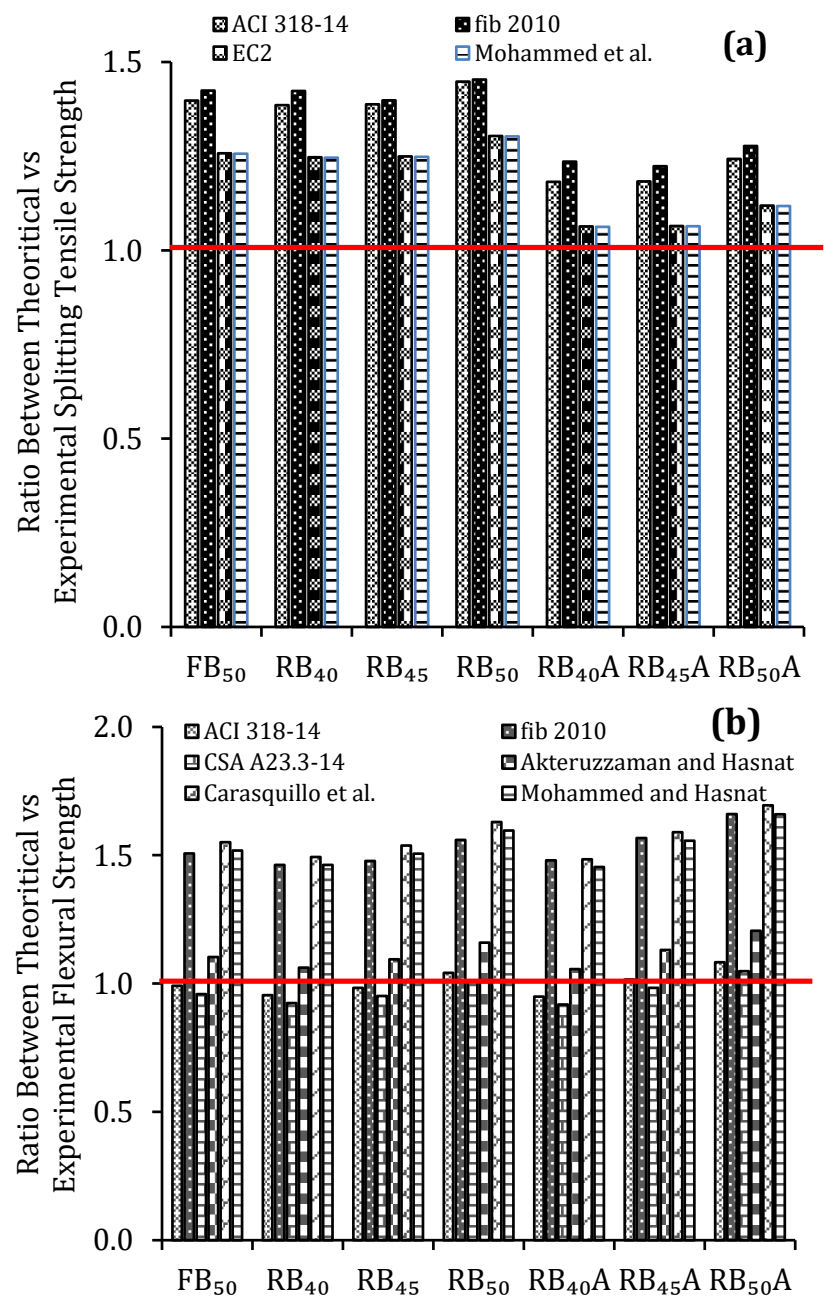

Figure10: Ratio between theoretical and experimental values of (a) splitting tensile strength, and (b) flexural strength using available equations 


\section{CONCLUSIONS}

From the experimental program carried out in the present study, the following conclusions can be drawn:

- The slump values and air content of all RBA concrete without admixture show lower slump values and higher air content values than that of the control mix which can be improved by incorporating waterreducing superplasticizer into RBA concrete.

- The compressive strengths of RBA concrete are slightly decreased compared to virgin FBA concrete for all ages up to $8.8 \%$. After adding admixture with this RBA concrete this disadvantage can be improved up to $16.7 \%$. It is possible to make more than $40 \mathrm{MPa}$ concrete with RBA aggregate which can be easily used in any structural member.

- The compressive strengths of concrete at $600^{\circ} \mathrm{C}$ are decreased by almost $15.6 \%$ compared to $400^{\circ} \mathrm{C}$. Though the compressive strengths are decreased at high temperature $\left(600^{\circ} \mathrm{C}\right)$, they are still more than 28 $\mathrm{MPa}$ without admixture and more than $33 \mathrm{MPa}$ with admixture.

- For RBA concrete, the splitting tensile strengths show more than $2.45 \mathrm{MPa}$. The tensile strengths are slightly $(7.8 \%)$ decreased for RBA concrete compared to virgin FBA concrete and it can be easily compensated by adding admixture into the concrete.

- The flexural strength is decreased by almost $9.1 \%$ for recycled brick compared to virgin FBA concrete. After adding admixture into the RBA concrete, the flexural strengths are increased by $6.1 \%, 4.6 \%$, and $3.3 \%$ compared to the combinations without admixture for the $w / c$ ratio of $0.40,0.45$, and 0.50 , respectively.

- The available design guidelines and equations overpredict the splitting tensile and flexural strengths of recycled brick concrete. Extensive investigation is needed for predicting the actual behavior of recycled brick aggregate.

\section{DECLARATION OF COMPETING INTEREST}

The authors declare that there are no conflict of interest.

\section{ACKNOWLEDGEMENTS}

This study was funded by the Military Institute of Science and Technology (MIST) and work was carried out at the Concrete Laboratory of Civil Engineering Department, MIST, Dhaka, Bangladesh.

\section{REFERENCES}

ACI 318-14. (2014). Building Code Requirements for Structural Concrete and Commentary. American Concrete Institute.

Ajdukiewicz, A., \& Kliszczewicz, A. (2002). Influence of recycled aggregates on mechanical properties of hs/hpc. Cement \& Concrete Composites, 24, 269-279.
Akhtaruzzaman, A., \& Hasnat, A. (1983). Properties of Concrete Using Crushed Brick as Aggregates. Concrete International, 5(2), 58-63.

Alam, M. S., Slater, E., \& Billah, A. H. M. M. (2013). Green concrete made with rca and frp scrap aggregate: Fresh and hardened properties. Journal of Materials in Civil Engineering, 25, 1783-1794.

Arabiyat, S., Abdel Jaber, M. t., Katkhuda, H., \& Shatarat, N. (2021). Influence of using two types of recycled aggregates on shear behavior of concrete beams. Construction and Building Materials, 279, 122475. doi:https://doi.org/10.1016/j.conbuildmat.2021.122475

ASTM C33/C31M. (2018). Standard Specification for Concrete Aggregates. ASTM International, West Conshohocken, PA

ASTM C39. (2018). Standard Test Method for Compressive Strength of Cylindrical Concrete Specimens. ASTM International, West Conshohocken, PA.

ASTM C78/C78M. (2016). Standard Test Method for Flexural Strength of Concrete (Using Simple Beam with Third-Point Loading). ASTM International, West Conshohocken, PA.

ASTM C143. (2015). Standard Test Method for Slump of Hydraulic-Cement Concrete. ASTM International, West Conshohocken, PA.

ASTM C231. (2017). Standard Test Method for Air Content of Freshly Mixed Concrete by the Pressure Method. ASTM International, West Conshohocken, PA.

ASTM C494/C494M. (2019). Standard Specification for Chemical Admixtures for Concrete. In ASTM International (pp. West Conshohocken, PA).

ASTM C496. (2014). Standard Test Method for Splitting Tensile Strength of Cylindrical Concrete Specimens. ASTM International, West Conshohocken, PA.

Barcelo, L. (2013). A path towards more sustainable cement. ACI fall convention, Phoenix, USA, 24.

C\&D Waste Management Guide. (2016). Minimizing construction \& demolition waste. . Department of Health, Office of Solid Waste Management, Honolulu, HI.

Carrasquillo, R. L., Nilson, A. H., \& Slate, F. O. (1981). Properties of High-Strength Concrete Subjected to Short-Term Loads. ACI Journal Proceedings, 78(3), 171-178.

CSA A23.3-14. (2014). Design of Concrete Structures. Canadian Standards Association.

EN 1992-1-1. (2005). Eurocode 2-Design of Concrete Structures-Part 1-1: General Rules and Rules for Buildings. Thomas Telford, London, UK.

fib. (2010). fib Model Code for Concrete Structures. International Fedaration for Structural Concrete.

Hossain, F. M. Z., Shahjalal, M., Islam, K., Tiznobaik, M., \& Alam, M. S. (2019). Mechanical properties of recycled aggregate concrete containing crumb rubber and polypropylene fiber. Construction and Building Materials, 225, 983-996.

Islam, M. J., Dipta, I. A., \& Rahat, M. (2018). Investigation of recycled poly-ethylene terephthalate (PET) as partial replacement of coarse aggregate in concrete. Journal of Civil Engineering (IEB), 46(1), 11-20. 
Islam, M. J., Meherier, M. S., \& Islam, A. K. M. R. (2016). Effects of waste pet as coarse aggregate on the fresh and harden properties of concrete. Construction and Building Materials, 125, 946-951.

Islam, M. J., Rahman, J., Nawshin, S., \& Islam, M. M. (2020). Comparative Study of Physical and Mechanical Properties of Machine and Manually Crushed Brick Aggregate Concrete. MIST International Journal of Science and Technology, 8(1). doi:10.47981/j.mijst.08(01)2020.188(01-09)

Kou, S. C., Poon, C. S., \& Etxeberria, M. (2011). Influence of recycled aggregates on long term mechanical properties and pore size distribution of concrete. Cement \& Concrete Composites, 33, 286-291.

Kou, S. C., Poon, C. S., \& Etxeberria, M. (2014). Residue strength, water absorption and pore size distributions of recycled aggregate concrete after exposure to elevated temperatures. Cement \& Concrete Composites, 53, 7382.

Mehta, P. K. (2009). Global concrete industry sustainability. ACI Concr. Int., 32(2), 45-48.

Mohammed, T. U., \& Hasnat, A. (2014). Modulus of rupture of concrete made with recycled brick aggregate. The 6th International Conference of Asian Concrete Federation, Seoul, Korea.

Mohammed, T. U., Hasnat, A., Awal, M. A., \& Bosunia, S. Z. (2013a). Recycling of brick aggregate concrete :An extended study on some key issues. Third International Conference on Sustainable Construction Materials and Technologies, Japan.
Mohammed, T. U., Hasnat, A., Awal, M. A., \& Bosunia, S. Z. (2013b). Recycling of brick aggregate concrete: Physical and mechanical properties. Third International Conference on Sustainable Construction Materials and Technologies, Japan.

Mohammed, T. U., Hasnat, A., Awal, M. A., \& Bosunia, S. Z. (2015). Recycling of brick aggregate concrete as coarse aggregate. Journal of Materials in Civil Engineering, 27(7).

Rodríguez-Robles, D., García-González, J., Juan-Valdés, A., Morán-Del Pozo, J. M., \& Guerra-Romero, M. I. (2015). Overview regarding construction and demolition waste in spain. Environ. Technol., 36(23), 3060-3070

Shahjalal, M., Hossain, F. M. Z., Islam, K., Tiznobaik, M., \& Alam, M. S. (2019). Experimental study on the mechanical properties of recycled aggregate concrete using crumb rubber and polypropylene fiber. CSCE Annual Conference, Canada.

Shahjalal, M., Islam, K., Rahman, J., Ahmed, K. S., Karim, M. R., \& Billah, A. H. M. M. (2021). Flexural response of fiber reinforced concrete beams with waste tires rubber and recycled aggregate. Journal of Cleaner Production, 278 , 123842 . doi:https://doi.org/10.1016/j.jclepro.2020.123842

Smith, J. T. (2010). Recycled concrete aggregate - A viable aggregate source for concrete pavements. (PhD), University of Waterloo, Canada. 